\title{
Saccadic Eye Movements in Mild Traumatic Brain Injury: A Pilot Study
}

\author{
Sarah J. Mullen, Yeni H. Yücel, Michael Cusimano, Tom A. Schweizer, \\ Anton Oentoro, Neeru Gupta
}

\begin{abstract}
Objective: To investigate whether repeat saccadic reaction time (SRT) measurements using a portable saccadometer is useful to monitor patients with mild traumatic brain injury (mTBI). Methods: Seven patients with newly-diagnosed mTBI and five agematched controls were prospectively recruited from an Emergency Department. Saccadic eye movements, symptom self-reporting and neuropsychological tests were performed within one week of injury and again at follow-up three weeks post-injury. Control patients underwent saccade recordings at similar intervals. Results: Median saccade reaction times were significantly prolonged within one week post-injury in mTBI compared to controls. At follow-up assessment there was no significant between-groups difference. Changes in median SRT between the two assessments were not statistically significant. Four of the seven mTBI patients showed significantly increased SRT at follow-up; three of the mTBI patients and all controls showed no significant change. Among the three mTBI patients with persistent decreased SRT, two experienced loss of consciousness and reported the greatest symptoms, while the third was the only subject with significant decrease in neuropsychological testing scores at both assessments. Conclusion: In three of seven mTBI patients, saccadic eye movements remained delayed within three weeks post-injury. These three patients also showed persistent symptoms or no improvement on neuropsychological testing. This pilot study using a portable saccadometer suggests that comparing SRT from three weeks post-injury to that within one week of injury may be useful for early detection of a subpopulation at risk of persistent disability from mTBI. This finding suggests that further investigation in a large study population is warranted.
\end{abstract}

RÉSUMÉ: Les saccades oculaires dans le traumatisme cérébral léger : une étude pilote. Objectif : Le but de l'étude était d'évaluer si les mesures répétées du temps de réaction saccadique (TRS) au moyen d'un saccadomètre portable est utile pour le suivi des patients atteints d'un traumatisme cérébral léger (TCL). Méthode : Sept patients chez qui un diagnostic de TCL venait d'être posé et 5 sujets témoins appariés pour l'âge ont été recrutés prospectivement au département des urgences. Les saccades oculaires, les symptômes rapportés par le patient et les tests neuropsychologiques ont été documentés dans la semaine suivant le traumatisme et de nouveau au moment du suivi, 3 semaines après le traumatisme. L'enregistrement des saccades chez les patients témoins a été fait aux mêmes intervalles. Résultats : Les temps médians de réaction saccadique étaient prolongés significativement au cours de la semaine suivant le traumatisme chez les patients ayant subi un TCL par rapport aux témoins. Au moment de l'évaluation de suivi, il n'existait pas de différence significative entre les deux groupes de patients. Les changements dans le TRS médian entre les deux évaluations n'étaient pas significatifs au point de vue statistique. Quatre des 7 patients atteints d'un TCL avaient un TRS augmenté de façon significative au moment du suivi ; aucun changement n'a été observé chez 3 des patients atteints d'un TCL et chez les témoins. Parmi les trois patients atteints d'un TCL qui ont présenté une diminution persistante du TRS, 2 avaient eu une perte de conscience et rapporté les symptômes les plus sévères, alors que le troisième était le seul chez qui une diminution significative des scores aux tests neuropsychologiques lors des deux évaluations avait été notée. Conclusion : Chez 3 des 7 patients ayant subi un TCL le retard des saccades oculaires persistait 3 semaines après le traumatisme. Ces 3 patients présentaient également des symptômes persistants ou aucune amélioration lors des tests neuropsychologiques. Cette étude pilote effectuée au moyen d'un saccadomètre portable suggère que la comparaison du TRS evalué 3 semaines après le traumatisme à celui fait dans la semaine suivant le traumatisme pourrait être utile pour détecter précocement la sous-population de patients à risque d'invalidité persistante suite à un TCL. Selon nos observations, il serait justifié de procéder à des recherches sur un échantillon de patients plus considérable.

Can J Neurol Sci. 2014; 41: 58-65

Mild traumatic brain injury (mTBI) presents a major public health concern worldwide..$^{1-5}$ Approximately $10-15 \%$ of those who sustain mTBI develop long-term disability with health, psychosocial functioning and quality of life consequences. ${ }^{6}$ Currently, there is no consensus regarding the diagnosis and treatment of mTBI, ${ }^{4,7}$ and assessment of clinical symptoms and signs and other indicators are not able to predict which patients will develop permanent disability compared to those with a better prognosis. Development of novel biomarkers to predict this high-risk population is critical to improve follow-up and for optimal use of clinical resources. It is therefore essential, from a clinical perspective, that we develop user-friendly, and cost- effective, surrogate markers to detect patients with persistent mTBI.

From the Ophthalmology \& Vision Sciences (SJM, YHY, AO, NG), Laboratory Medicine \& Pathobiology, Surgery (SJM, MC, TAS, AO), Division of Neurosurgery, Keenan Research Centre at the Li Ka Shing Knowledge Institute (SJM, YHY, MC, TAS, NG), Glaucoma \& Nerve Protection Unit (NG), St. Michael's Hospital, Toronto, Ontario, Canada.

Received April 2, 2013. Final Revisions Submitted July 11, 2013. Correspondence to: Yeni H. Yücel, Li Ka Shing Knowledge Institute of St. Michael's Hospital, 30 Bond Street, 209 LKSKI, Room 409, Toronto, Ontario, M5B 1W8, Canada. Email: yucely@smh.ca. 
Neuroanatomical/neurobiological correlates of mTBI have not yet been completely elucidated. Along with clinical assessment and neuropsychological tests, studies of saccadic eye movements may provide insights into mTBI. Saccades are rapid eye movements that move the line of sight between successive points of fixation. ${ }^{8,9}$ Their dynamic properties are well understood and easily measured, including reaction time, amplitude, peak velocity, duration, and frequency of errors. ${ }^{10}$ Reaction time, or latency, represents the time interval between presentation of a target and initiation of eye movement. ${ }^{10}$ In healthy individuals, reaction times fall within a normal range; alternatively, they may fall within a separate, faster range of reaction times which represents a subpopulation of "early response" saccades. ${ }^{11}$ Characteristic variation in saccadic reaction times across trials is a reflection of cortical decision time. ${ }^{12}$ Prolonged saccadic reaction times have been observed in various optic nerve pathologies that convey visual signals to the saccade generating network, ${ }^{13,14}$ and we have recently shown that saccadic eye movements are delayed in glaucoma, the leading cause of world blindness. ${ }^{15}$ Monitoring an individual's saccadic reaction time rate ( $1 /$ (reaction time) ) may also represent an important quantitative approach to assessing the consequences of this form of head injury. ${ }^{16}$ Studies in severe TBI with persistent symptoms from a chronic care facility showed persistent prolongation of reaction time. ${ }^{17}$ Reflexive saccades have been rarely studied in mTBI patients. An early study showed that the saccade reaction time was not altered in mTBI ${ }^{18,19}$ However, a recent study of amateur boxers showed prolonged reaction time immediately after fight, and progressive shortening with recovery within two weeks after fight. ${ }^{16}$ Similarly, reaction time rate was decreased immediately following injury before returning to baseline. ${ }^{16}$ Based on these studies, it is not clear whether saccadic reaction time can be used to monitor patients with mTBI to detect those at risk of developing ongoing brain injury. We show here that reflexive

Table 1: Inclusion and exclusion criteria

\begin{tabular}{l|l}
\hline \multicolumn{1}{c|}{ Inclusion Criteria } & \multicolumn{1}{c}{ Exclusion Criteria } \\
\hline Age $\geq 18$ years & Age $>80$ years \\
\hline Abillity to provide consent & Medically unstable or intoxicated patients \\
\hline \multirow{2}{*}{$\begin{array}{l}\text { Non-penetrating head impact } \\
\text { occurring within 0-7 days of } \\
\text { presentation to ED meeting WHO } \\
\text { criteria for isolated mTB1 }\end{array}$} & $\begin{array}{l}\text { Patients taking psychotropic medications or } \\
\text { medications known to interfere with oculomotor } \\
\text { function or attention }\end{array}$ \\
\cline { 2 - 2 } & $\begin{array}{l}\text { Immunocompromised patients (HIV/AIDS or } \\
\text { taking immunosuppressive therapy) }\end{array}$ \\
\cline { 2 - 2 } $\begin{array}{l}\text { No history of head injury (control } \\
\text { subjects) }\end{array}$ & $\begin{array}{l}\text { History of neurological/neurodegenerative or eye } \\
\text { disease }\end{array}$ \\
\cline { 2 - 2 } $\begin{array}{l}\text { Normal or corrected to normal } \\
\text { visual acuity of at least 20/50 OU }\end{array}$ & History of incisional brain or eye surgery \\
\hline $\begin{array}{l}\text { Literacy/adequate English } \\
\text { language skills }\end{array}$ & History of psychiatric illness or substance abuse \\
\hline Grade 8 education or higher & $\begin{array}{l}\text { History of traumatic brain injury (prior to } \\
\text { presenting injury) }\end{array}$ \\
\hline
\end{tabular}

$\mathrm{ED}=$ Emergency Department; WHO=World Health Organization; GCS=Glasgow Coma Scale; LOC=loss of consciousness; PTA=posttraumatic amnesia; $\mathrm{OU}=$ both eyes (oculus uterque) saccadic reaction time have potential as a surrogate measure of dysfunction following mTBI in a tertiary care trauma center, and as a biomarker to detect those patients at risk of ongoing evidence of injury from mTBI.

\section{Material AND Methods}

\section{Participants}

Ethics approval was obtained from St. Michael's Hospital Research Ethics Board and all participants gave written informed consent prior to inclusion in the study. Inclusion and exclusion criteria for patients and controls are listed in Table $1 .{ }^{20-}$ ${ }^{23}$ Adults greater than 80 years of age were excluded because of aging effects on saccadic reaction times. ${ }^{24,25}$ Prior to the start of each assessment, all participants provided a medical history and underwent a screening neurological and eye examination. No participants were taking any medications which are known to directly or indirectly interfere with attention or oculomotor function. ${ }^{21}$ Baseline depressive symptoms were evaluated in both groups of participants using the Centre for Epidemiologic Studies Depression Scale (CES-D), ${ }^{26}$ as depression may affect saccadic reaction times. ${ }^{27}$ The CES-D is well-validated and reliable for screening depressive symptoms in the general population; ${ }^{26}$ however, it has also been validated as a sensitive screening tool for major depressive disorders in mild-tomoderate TBI patients. ${ }^{28,29}$ There were no significant differences on CES-D scores between mTBI group and controls (Mean \pm $\mathrm{SD}=6.57 \pm 4.72 ; 5.40 \pm 3.13$, respectively, $\mathrm{P}=0.64$; Table 2), using an independent-samples t-test.

Seven patients (male $(n=4)$; female $(n=3)$ ) with newly diagnosed mTBI (Tables 2 and 3) were included in this study. All patients were recruited upon presentation to the hospital's Emergency Department (ED). Mean age was 35 years (range: 18-57 years), and mean duration of education was 15.5 years (range: 12-20 years). Mechanisms of injury included sporting $(n=3)$, occupational $(n=2)$ and accidental $(n=2)$ incidents. Mild TBI was diagnosed clinically by an emergency physician. Mild TBI was defined according to the World Health Organization (WHO) criteria for isolated mTBI:20 Glasgow Coma Scale

Table 2: Demographics

\begin{tabular}{c|c|c|c}
\hline & Control & mTBI & Significance \\
\hline Number & 5 & 7 & - \\
\hline$\%$ Female & $40 \%$ & $33 \%$ & - \\
\hline Age (Mean \pm SD years) & $26.60 \pm 4.83$ & $35.28 \pm 15.35$ & $P=0.257$ \\
\hline Education (years) & - & $15.5 \pm 3.68$ & - \\
\hline CES-D & $5.40 \pm 3.13$ & $6.57 \pm 4.72$ & $P=0.64$ \\
\hline
\end{tabular}

Age and education measured in total years. CES-D to detect depression measured as total score. Significance P-values represent the outcome of an independent samples t-test. Years of education not collected for control group (relevant only to neuropsychological testing). 
Table 3: Participant summary data for mTBI patients and controls

\begin{tabular}{c|c|c}
\hline \multicolumn{3}{|c}{ Control } \\
\hline$\#$ & Age (yrs) & Gender \\
\hline 1 & 27 & $\mathrm{M}$ \\
\hline 2 & 21 & $\mathrm{~F}$ \\
\hline 3 & 27 & $\mathrm{M}$ \\
\hline 4 & 34 & $\mathrm{~F}$ \\
\hline 5 & 24 & \\
\hline \multicolumn{3}{|c|}{$\mathrm{mTBI}$} \\
\hline$\#$ & Age (yrs) & $\mathrm{Gender}$ \\
\hline 1 & 53 & $\mathrm{M}$ \\
\hline 2 & 19 & $\mathrm{~F}$ \\
\hline 3 & 18 & $\mathrm{M}$ \\
\hline 4 & 39 & $\mathrm{~F}$ \\
\hline 5 & 57 & $\mathrm{M}$ \\
\hline 6 & 32 & $\mathrm{~F}$ \\
\hline 7 & 29 &
\end{tabular}

(GCS) 13-15 after 30 minutes following presentation to ED manifested by at least one of the following symptoms: Loss of consciousness (LOC) $\leq 30$ minutes; post-traumatic amnesia $($ PTA $) \leq 24$ hours and/or other transient neurological abnormalities. Participants underwent initial testing within one week of injury (Mean=4 days post-injury, range: three hours -six days), and follow-up testing approximately two weeks later (Mean=16 days post-injury, range: 14-21 days). Timing of assessments was based on the natural history of uncomplicated mTBI, as post-concussive symptoms and neurocognitive function recover within the first ten days following injury. ${ }^{30-32}$

Five age-matched neurologically healthy individuals (Tables 2 and 3 ) male $(n=3)$; female $(n=2)$ ) with no history of eye disease (Mean=27 years, range: $21-34$ years) served as a control group. They underwent saccadic eye movement recordings at first and follow-up assessments (Mean interval=12 days; range 6-14 days).

\section{Rivermead Post-Concussion Symptoms Questionnaire (RPSQ)}

Participants rated the presence and severity of 16 symptoms commonly experienced following mTBI on the RPSQ. ${ }^{33-34}$ The problem-status of symptoms was measured on a scale from 0-4 $(0=$ not experienced at all after the injury, $1=$ experienced but no more of a problem compared to before the injury, $2=a$ mild problem, $3=$ a moderate problem, $4=\mathrm{a}$ severe problem). For both assessments, the assessment period for answers on the RPSQ was extended from 'the previous 24 hours' to 'the time postinjury'. The key measure was the cumulative total of all symptoms.

\section{Neuropsychological Testing}

Many studies describe variable sensitivity of neuropsychological testing but identify significant change on
Hopkins Verbal Learning Test (HVLT). ${ }^{35-40}$ Neuropsychological tests administered to mTBI patients included HVLT-Revised (HVLT-R) Delayed Recall and Discrimination Index. The neuropsychological assessment was completed by a doctoral student (S.J.M.). The student was trained in the administration of neuropsychological testing and closely supervised by a cognitive neuroscientist (T.A.S.). ${ }^{41}$ Standardized instructions were followed, and results were compared with normative data. ${ }^{42}$

\section{Eye Movement Recordings}

Horizontal displacement of the eye was recorded using noninvasive infrared scleral oculometry by a miniaturized, portable, head-mounted saccadometer (Ober Consulting, Poznan, Poland). ${ }^{43}$ Subjects were seated in a room with luminance of $500 \mathrm{~cd} / \mathrm{m}^{2}$ (measured with Minolta Luminance Meter LS-100, Osaka, Japan) at a distance of $1.5 \mathrm{~m}$ from a matte white surface. A headpiece containing three low-power lasers that project the target stimuli in front of the subject was applied over the bridge of the nose, eliminating the need for head stabilization. Test stimuli comprised three red high contrast $\left(13 \mathrm{~cd} / \mathrm{m}^{2}\right)$ targets subtending $0.1^{\circ}$ in diameter at $0^{\circ}, 10^{\circ}$ left and $10^{\circ}$ right along the frontal plane at eye level. Viewing and recording were performed binocularly. Calibration was performed before each experiment.

Each experiment consisted of a 10-degree step task in order to evoke "reflexive" saccades initiated as a direct result of the visual stimulus. The data recorded from each experiment was used to determine reaction time, duration, amplitude, peak velocity and direction. Output was sampled at a rate of $1 \mathrm{kHz}$ and linear range was within $7 \%$ for up to $\pm 30^{\circ}$ (Ober Consulting). ${ }^{43}$ Each experimental trial began with a central target (presented during a random fore-period of 500-1000 ms), which was extinguished and followed by the appearance of a peripheral target located $10^{\circ}$ randomly to the right or left. The stimuli remained projected until the subject either initiated a saccade, or $2000 \mathrm{~ms}$ had elapsed. Experiments lasted 15 minutes during which up to 200 trials were conducted. Instructions were consistent across experiments.

Raw saccadometry data was downloaded to a computer for analysis using LatencyMeter Version 4.9 software (Ober Consulting), which automatically excludes blinks and head movements. Trials with latencies between 50 and $600 \mathrm{~ms}$ were analyzed, removing anticipatory saccades $(<50 \mathrm{~ms})$ and no response trials $(>600 \mathrm{~ms}) .{ }^{44-46}$ If at any assessment, the number of saccade trials was greater than the other, the trials with greater number was trimmed to have the same number of saccades as the assessment with lesser number of saccades. The median reaction time and reaction time rate $(1 /$ (reaction time) $)$ were calculated. Responses with reaction times between $50 \mathrm{~ms}$ and $100 \mathrm{~ms}$ were indicative of express saccades ${ }^{11,24,25,47-50}$ and their frequency was counted. Trials representing directional errors were analyzed separately.

\section{Statistical Analyses}

Statistical analyses were performed using MATLAB Version 7.1 software (The Mathworks Inc, Natick, MA, USA) and SAS 9.2 (SAS Institute Inc, Cary, NC, USA). We performed twotailed t-tests to compare the mean of the median reaction times for the mTBI group to the mean of the median reaction times for 
Table 4A: Rivermead Post-Concussion Symptoms Questionnaire (RPSQ) and Hopkins Verbal Learning Test-Revised (HVLT-R) Scores [First Assessment]

\begin{tabular}{c|c|c|c|c}
\hline $\begin{array}{c}\text { mTBI } \\
\text { Patients }\end{array}$ & $\begin{array}{c}\text { RPSQ } \\
\text { Scores }\end{array}$ & $\begin{array}{c}\text { HVLT-R } \\
\text { Total Trials }\end{array}$ & $\begin{array}{c}\text { HVLT-R } \\
\text { Delayed Recall }\end{array}$ & $\begin{array}{c}\text { HVLT-R } \\
\text { Recognition Index }\end{array}$ \\
\hline 1 & 0 & 26 & 6 & 8 \\
\hline 2 & 19 & 22 & 5 & 11 \\
\hline 3 & 9 & 29 & 11 & 10 \\
\hline 4 & 9 & 25 & 9 & 10 \\
\hline 5 & 21 & 29 & 9 & 10 \\
\hline 6 & 19 & 21 & 8 & 8 \\
\hline 7 & 36 & 28 & 10 & 11 \\
\hline Mean & 16.14 & 25.71 & 8.28 & 9.71 \\
\hline SD & 11.52 & 2.14 & 1.25 & 3.25 \\
\hline
\end{tabular}

the control group at first and follow-up assessments. We subtracted median reaction time at follow-up from median reaction time at first assessment and used a two-tailed t-test to compare the means of the differences. We used a two-tailed t-test to compare reaction time rate at first assessment to that at followup assessment for each mTBI patient and each control participant. (P-values less than or equal to 0.05 were considered statistically significant.) Two-tailed t-tests were used to compare other saccade parameters of the mTBI group to those of the controls.

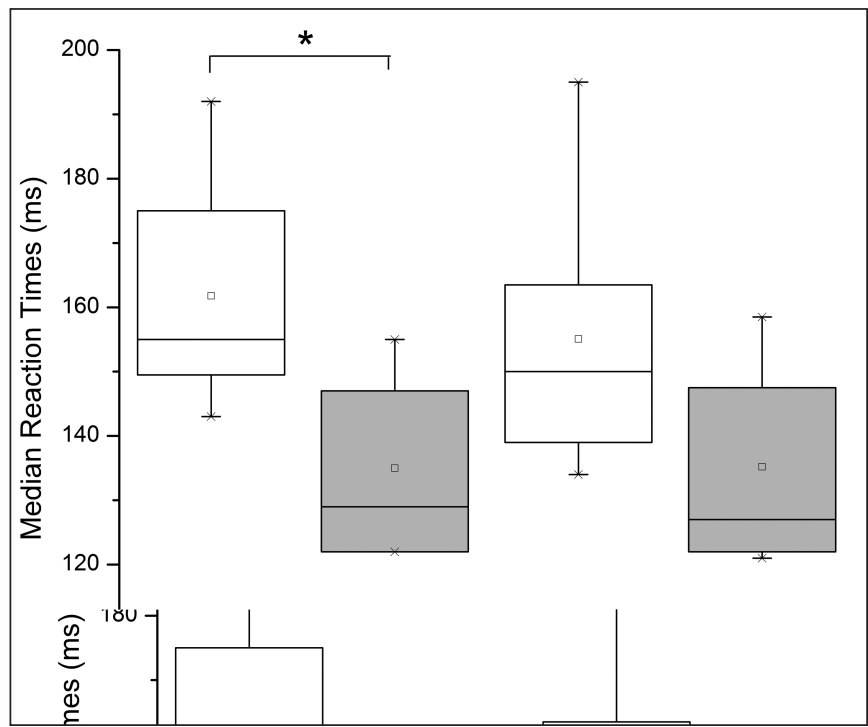

Figure: Boxplots of median saccade reaction times ( $m s)$ at two assessment times. The area marked by an asterisk represents a significant difference in the means of the median reaction times between the $\mathrm{mTBI}$ group $(161.8 \pm 17.4 \mathrm{~ms})$ and the control group $(135.0 \pm 15.1 \mathrm{~ms})$ at first assessment. At follow-up, the mTBI group shows increased reaction time $(155.1 \pm 20.5 \mathrm{~ms})$, whereas the control group is stable $(135.2 \pm 16.9 \mathrm{~ms})$. The difference between the means of the two groups is no longer significant.
Table 4B: Rivermead Post-Concussion Symptoms Questionnaire (RPSQ) and Hopkins Verbal Learning Test-Revised (HVLT-R) Scores [Follow-up Assessment]

\begin{tabular}{c|c|c|c|c}
\hline mTBI Patients & $\begin{array}{c}\text { RPSQ } \\
\text { Scores }\end{array}$ & $\begin{array}{c}\text { HVLT-R } \\
\text { Total Trials }\end{array}$ & $\begin{array}{c}\text { HVLT-R } \\
\text { Delayed } \\
\text { Recall }\end{array}$ & $\begin{array}{c}\text { HVLT-R } \\
\text { Recognition Index }\end{array}$ \\
\hline 1 & 0 & 25 & 6 & 7 \\
\hline 2 & 7 & 26 & 12 & 11 \\
\hline 3 & 7 & 32 & 11 & 11 \\
\hline 4 & 1 & 27 & 11 & 10 \\
\hline 5 & 27 & 35 & 12 & 11 \\
\hline 6 & 9 & 27 & 9 & 10.42 \\
\hline 7 & 15 & 31 & 10 & 1.61 \\
\hline Mean & 9.43 & 29 & 10.14 & $11.15 \pm .73$ \\
\hline SD & 9.24 & 3.69 & 2.11 & \pm 2.18 \\
\hline $\begin{array}{c}\text { Normative data } \\
\text { (Mean } \pm \text { SD) }^{36}\end{array}$ & - & $27.49 \pm 4.12$ & $10.24 \pm 1.20$ & \pm 3.47 \\
\hline $\begin{array}{c}\text { 95\% Confidence } \\
\text { Interval }\end{array}$ & - & \pm 8.09 & & \\
\hline
\end{tabular}

For mTBI patients, neuropsychological test scores were compared to $95 \%$ confidence interval of age- and-educationmatched normative data, which has been found to be more sensitive than using individualized baseline measures. ${ }^{42,51}$

\section{RESULTS}

Three of the seven mTBI patients (\#3,\#5 and\#7) experienced brief loss of consciousness. Mean score from the RPSQ was 16.14 (range: 0-36) at the first assessment following head injury (Tables 4A \& 4B). One patient (mTBI \#1) reported a score of 0 , indicating no symptoms, despite being clinically diagnosed with mTBI. At the follow-up assessment, the mean score on the RPSQ was 9.43 (range 0-27). Two patients (mTBI \#5 and mTBI \#7) continued to experience significant physical and cognitive symptoms stemming from mTBI, as demonstrated by highest RSPQ scores at the follow-up assessment of mTBI group (RPSQ scores of 27 and 15, respectively). One of the mTBI patients (mTBI \#1) who did not present any symptoms (RPSQ scores) showed persistent and significant decrease in HVLT-R recall and recognition indexes (Tables 4A \& 4B) at both assessments.

\section{Saccadic Eye Movement Recordings}

At the first assessment within one week after injury, median reaction time of the mTBI group was significantly prolonged compared with controls $(161.8 \pm 17.4 \mathrm{~ms}$ vs. $135.0 \pm 15.1 \mathrm{~ms} ; t$ test; $\mathrm{P}=0.020$; Table 5). At the follow-up assessment within three weeks after injury, median reaction time of the mTBI group was prolonged compared with controls but did not reach statistically significant level $(155.1 \pm 20.5 \mathrm{~ms}$ vs. $135.2 \pm 16.9 \mathrm{~ms}$; $t$-test; $\mathrm{P}=0.106$; Table 5). The Figure illustrates the median reaction times in mTBI group and controls during the first and follow-up assessments.

Changes in median reaction time between first and follow-up assessments in mTBI group were not statistically significant 
Table 5: Median reaction time at first and follow-up assessments and t-test results for reaction time rate for $\mathrm{mTBI}$ patients and controls

\begin{tabular}{|c|c|c|c|c|c|}
\hline \multicolumn{4}{|c|}{ Reaction Times } & \multicolumn{2}{|r|}{$t$-tests ${ }^{\mathrm{a}, \mathrm{b}}$} \\
\hline & Median of $1^{\text {st }}$ & $\begin{array}{c}\text { Median } \\
\text { of } 2^{\text {nd }}\end{array}$ & Change $1^{\text {st }}-2^{\text {nd }}$ & $\begin{array}{c}\text { Number of } \\
\text { trials }(n)\end{array}$ & $\begin{array}{c}P- \\
\text { value }\end{array}$ \\
\hline mTBI \#1 & 155.0 & 150.0 & 5.0 & 166 & 0.113 \\
\hline mTBI \#2 & 149.5 & 134.0 & 15.5 & 124 & $0.002^{* *}$ \\
\hline mTBI \#3 & 150.0 & 139.0 & 11.0 & 181 & $0.003^{* *}$ \\
\hline mTBI \#4 & 175.0 & 163.5 & 11.5 & 200 & $<0.001^{* * *}$ \\
\hline mTBI \#5 & 192.0 & 195.0 & -3.0 & 145 & 0.409 \\
\hline mTBI \#6 & 168.0 & 159.0 & 9.0 & 197 & $<0.001^{* * *}$ \\
\hline mTBI \#7 & 143.0 & 145.0 & -2.0 & 189 & 0.099 \\
\hline Mean $\pm S D$ & $161.8 \pm 17.4$ & $155.1 \pm 20.5$ & $6.7 \pm 7.0$ & & \\
\hline Control \#1 & 122.0 & 121.0 & 1.0 & 199 & 0.603 \\
\hline Control \#2 & 155.0 & 158.5 & -3.5 & 140 & 0.288 \\
\hline Control \#3 & 122.0 & 122.0 & 0.0 & 199 & 0.520 \\
\hline Control \#4 & 147.0 & 147.5 & -0.5 & 200 & 0.238 \\
\hline Control \#5 & 129.0 & 127.0 & 2.0 & 198 & 0.752 \\
\hline Mean士 SD & $135.0 \pm 15.1$ & $135.2 \pm 16.9$ & $-0.2 \pm 2.1$ & & \\
\hline \multirow[t]{2}{*}{$t$-tests ${ }^{\mathrm{b}, \mathrm{c}}$} & $t=2.767$ & $t=1.777$ & $t=0.938$ & & \\
\hline & $P=0.020^{*}$ & $P=0.106$ & $P=0.061$ & & \\
\hline
\end{tabular}

${ }^{a}$ These two-tailed t-tests were performed on reaction time rates, i.e., 1/(reaction time). If one assessment was longer than the other, the longer one was trimmed to have the same number of reaction times as the shorter one. ${ }^{\mathrm{b}}$ Asterisks indicate: $* 0.01<\mathrm{P} \leq 0.05$; $* * 0.001<\mathrm{P} \leq 0.01$; *** $\mathrm{P}$ $\leq 0.001$. $^{\text {T These }}$ t-tests are two-tailed tests to compare the median reaction times (or change in median reaction times) of the seven mTBI subjects to the median reaction times (or change in median reaction times) of the five controls.

compared to controls $(6.7 \pm 7.0 \mathrm{~ms}$ vs. $-0.2 \pm 2.1 \mathrm{~ms}, \mathrm{P}=0.061$, Table 5).

Reaction time rate at follow-up assessment was significantly increased compared to that measured at the first assessment in four of the seven mTBI patients (\#2, \#3, \#4, and \#6), while reaction time rate did not show significant change between first and follow-up assessments in three (\#1,\#5 and \#7) of the seven mTBI patients (Table 5). None of the five control subjects showed any significant change in reaction time rate in follow-up assessment compared to that measured at the first assessment. Table 5 shows P-values for each of the mTBI patients and controls.

At the first assessment, among the other saccadic parameters, only frequency of express saccades was significantly decreased in mTBI group compared to controls $(2.42 \pm 1.84 \%$; $10.18 \pm$ $5.55 \%$; t-test; $\mathrm{P}<0.006$; Table $6 \mathrm{~A}$ ). The saccadic parameters other than reaction time and reaction time rate did not show significant change at the follow-up assessment within three weeks after injury (Table 6B).

\section{DisCUSSION}

In our pilot study, the median reaction times of controls at both initial and follow-up assessments were similar to reported values. ${ }^{45,52,53}$

Complex saccade measurements, such as anti-saccades ${ }^{19}$ and memory-population ${ }^{18,19}$ have shown saccade alteration in mTBI. Until recently, significant alterations in reflexive saccades have only been demonstrated in severe TBI. ${ }^{17}$ Heitger et $a l^{54}$ reported no significant difference in saccadic reaction time measured approximately four to five months following injury, between cases of mTBI with prolonged symptoms and patients who had recovered. Pearson et al ${ }^{16}$ found saccadic reaction times were delayed in mild TBI in a completely reversible manner following boxing. There are no studies where saccades were measured within three weeks post-injury in mTBI patients who needed acute care in a tertiary care trauma hospital setting. Our pilot data confirms that saccadic reaction times are prolonged in mTBI patients within one week following injury. At the time of the second assessment within three weeks after injury, there was no longer a difference between mTBI patients and controls; this finding was corroborated by an improvement of symptoms in four of the participants. These changes were observed alongside resolving symptom reporting, and scores on neuropsychological testing in most patients. In addition, we demonstrated for the first time that in a significant proportion of patients, saccadic reaction time rate did not show any significant change, and saccades remained delayed at the follow-up assessment within three weeks after injury. No changes in reaction time rates between first and follow-up assessment were detected in controls.

In our study, there was some correlation between saccadic reaction times and self-reporting symptoms, as well as some of the neuropsychological testing results. Three of mTBI patients and all five control participants showed no significant change in reaction time rate. Among these three mTBI patients who had 
Table 6A: Other saccadic parameters at first assessment

\begin{tabular}{|c|c|c|c|c|c|}
\hline Subject ID & $\begin{array}{l}\text { Median } \\
\text { Duration } \\
\quad(\mathrm{ms})\end{array}$ & $\begin{array}{c}\text { Median } \\
\text { Amplitude } \\
\left(^{\circ}\right)\end{array}$ & $\begin{array}{c}\text { Median } \\
\text { Peak } \\
\text { Velocity } \\
(\% / \mathrm{ms})\end{array}$ & $\begin{array}{c}\text { Express } \\
\text { Saccades } \\
(\text { cum\%) }\end{array}$ & $\begin{array}{l}\text { Incorrect } \\
\text { Responses } \\
\text { (frequency) }\end{array}$ \\
\hline mTBI \#1 & 46 & 9.5 & 451 & 1.8 & 3 \\
\hline $\mathrm{mTBI} \# 2$ & 56 & 13.6 & 430 & 2.4 & 2 \\
\hline $\mathrm{mTBI} \# 3$ & 48 & 9.3 & 411 & 6.3 & 0 \\
\hline mTBI \#4 & 48 & 9.4 & 528 & 1.5 & 1 \\
\hline mTBI \#5 & 50 & 9.4 & 365 & 1.9 & 13 \\
\hline mTBI \#6 & 51 & 10.6 & 358 & 0.5 & 0 \\
\hline mTBI \#7 & 51 & 9.8 & 359 & 2.6 & 0 \\
\hline Mean & 50 & 10.22 & 414.57 & 2.42 & 2.71 \\
\hline $\mathrm{SD}$ & 3.21 & 1.55 & 62.16 & 1.84 & 4.68 \\
\hline C \#1 & 50.3 & 12.7 & 448.8 & 14.1 & 0 \\
\hline $\mathrm{C} \# 2$ & 49.2 & 10 & 417.4 & 0.7 & 0 \\
\hline $\mathrm{C} \# 3$ & 48.6 & 10.8 & 443.3 & 10 & 0 \\
\hline C \#4 & 49.5 & 8.6 & 334.8 & 14 & 0 \\
\hline $\mathrm{C} \mathrm{\# 5}$ & 46 & 12.5 & 546.2 & 12.1 & 0 \\
\hline Mean & 48.72 & 10.92 & 438.1 & 10.18 & 0 \\
\hline SD & 1.63 & 1.72 & 75.7 & 5.55 & 0 \\
\hline$P-$ value & 0.436 & 0.483 & 0.567 & 0.006 & 0.229 \\
\hline
\end{tabular}

Saccadic parameters (raw values) for injured and control participants on the first assessment. $\mathrm{C}=$ control; $\mathrm{SD}=$ standard deviation
Table 6B: Other saccadic parameters at follow-up assessment

\begin{tabular}{|c|c|c|c|c|c|}
\hline $\begin{array}{l}\text { Subject } \\
\text { ID }\end{array}$ & $\begin{array}{c}\text { Median } \\
\text { Duration } \\
\text { (ms) }\end{array}$ & $\begin{array}{c}\text { Median } \\
\text { Amplitude } \\
\left({ }^{\circ}\right)\end{array}$ & $\begin{array}{l}\text { Median Peak } \\
\text { Velocity }(\% / m s)\end{array}$ & $\begin{array}{l}\text { Express } \\
\text { Saccades } \\
\text { (cum\%) }\end{array}$ & $\begin{array}{c}\text { Incorrect } \\
\text { Responses } \\
\text { (frequency) }\end{array}$ \\
\hline mTBI \#1 & 47 & 10.5 & 430.7 & 1.8 & 1 \\
\hline mTBI \#2 & 57 & 10.7 & 330.9 & 8.8 & 0 \\
\hline mTBI \#3 & 52 & 9.5 & 367 & 9.4 & 0 \\
\hline mTBI \#4 & 43 & 9.2 & 458.2 & 1.5 & 0 \\
\hline mTBI \#5 & 46 & 11.5 & 457.2 & 2.1 & 21 \\
\hline mTBI \#6 & 51 & 12.5 & 412 & 1 & 0 \\
\hline mTBI \#7 & 49 & 9.6 & 349.6 & 1 & 0 \\
\hline Mean & 49.28 & 10.5 & 400.8 & 3.65 & 3.14 \\
\hline SD & 4.572 & 1.19 & 51.87 & 3.74 & 7.88 \\
\hline C \#1 & 49 & 9.9 & 353.5 & 11 & 0 \\
\hline C \#2 & 50 & 13.5 & 559.3 & 1.6 & 0 \\
\hline C \#3 & 50 & 12.2 & 446 & 14.1 & 0 \\
\hline C \#4 & 50 & 8.6 & 307.9 & 7.6 & 2 \\
\hline C \#5 & 42 & 9.6 & 559.9 & 10.2 & 1 \\
\hline Mean & 48.2 & 10.76 & 445.32 & 8.9 & 0.6 \\
\hline SD & 3.49 & 2.02 & 115.58 & 4.69 & 0.89 \\
\hline$P-$ value & 0.666 & 0.784 & 0.457 & 0.056 & 0.430 \\
\hline
\end{tabular}

Saccadic parameters (raw values) for injured and control participants on the follow-up assessment. $\mathrm{C}=$ control; $\mathrm{SD}=$ standard deviation

Interestingly, both of these patients were female, which has been identified as a risk factor for persistent symptoms. ${ }^{57,58}$ While it is not yet clear whether these two patients were developing chronic sequelae from $\mathrm{mTBI}$, these findings suggest that reflexive saccadic latencies may be a useful biomarker to monitor for both recovery and persistent disease. Future research could include serial follow-up assessments in order to identify recovery from mTBI as well as transformation to ongoing mTBI, based on saccadic reaction times alongside more comprehensive neuropsychological measures. Since the neural substrate involved in saccade generation is different from that involved in the tested cognitive functions,$^{10}$ detailed neuroimaging studies will be needed to assess structural integrity of the neural pathways involved in saccade generation as well as neuropsychological functions.

There are a number of limitations to our pilot study. The sample size is small, and sample bias cannot be excluded, as our study is comprised of individuals who chose to seek medical attention following mTBI. However, representativeness of sample at the clinical setting of a tertiary care trauma centre, is suggested by age, gender and mechanisms of injury. ${ }^{59}$ Although there was no statistically significant difference between mean ages of the experimental and control groups, tighter agematching between-groups could minimize aging effects on saccadic reaction times. ${ }^{25}$ There is often a delay between time of injury and decision to seek medical attention. Individuals were tested at varying time courses of injury, based on time of presentation to Emergency Department. The limitations of neuropsychological testing are well-described ${ }^{60}$ and the use of computerized testing may have been able to overcome some of these weaknesses. Finally, saccadometry results as well as 
neuropsychological tests can be affected by variables such as fatigue which may occur independently of injury sequelae.

\section{CONCLUSION}

This pilot study shows for the first time that persistent prolonged saccadic reaction times in mTBI patients may separate patients with persistent mTBI from those with recovering mTBI. These preliminary results support the need for larger multidisciplinary investigation, including neuropsychological and neuroimaging studies, to validate whether saccadic reaction times, measured by a portable head-mounted saccadometer, may serve as a biomarker to monitor mTBI patients, and to detect those at risk of developing persistent mTBI.

\section{Ethical Adherence}

Ethics approval was obtained from our institution's Research Ethics Board and all participants gave written informed consent prior to inclusion in the study.

\section{ACKNOWLEDGMENTS/Disclosures}

This study was supported by the Ontario Neurotrauma Foundation, Glaucoma Research Society of Canada (NG, YY), Dorothy Pitts Research Fund (NG) and Canadian Institutes of Health Research Strategic Team Grant in Applied Injury Research \# TIR-103946. The authors thank Barbara Thomson MSc for her help with statistical analysis. The authors report no conflicts of interest in this work.

\section{REFERENCES}

1. Vos PE, Battistin L, Birbamer G, et al; EFNS Task Force. EFNS guideline on mild traumatic brain injury: report of an EFNS task force. Eur J Neurol. 2002;9(3):207-19.

2. Peloso PM, Carroll LJ, Cassidy JD, et al. Critical evaluation of the existing guidelines on mild traumatic brain injury. J Rehabil Med. 2004;(43 Suppl):106-12.

3. McCrea M, Kelly JP, Randolph C, Cisler R, Berger L. Immediate neurocognitive effects of concussion. Neurosurgery. 2002;50(5): 1032-42.

4. Maruta J, Lee SW, Jacobs EF, Ghajar J. A unified science of concussion. Ann N Y Acad Sci. 2010;1208:58-66.

5. McCrea M, Iverson GL, McAllister TW, et al. An integrated review of recovery after mild traumatic brain injury (mTBI): implications for clinical management. Clin Neuropsychol. 2009; 23(8):1368-90.

6. Kushner D. Mild traumatic brain injury: toward understanding manifestations and treatment. Arch Intern Med. 1998;158(15): 1617-24.

7. Tavender EJ, Bosch M, Green S, et al. Quality and consistency of guidelines for the management of mild traumatic brain injury in the emergency department. Acad Emerg Med. 2011;18(8):880-9.

8. Becker W. Metrics. In: Wurtz RH, Goldberg ME, editors. The neurobiology of saccadic eye movements. Amsterdam:Elsevier; 1989. p. 13-67.

9. Leigh JR, Zee DS, editors. The Saccadic System. In: The Neurology of Eye Movements. 3rd ed. New York: Oxford University Press; 1999. p. 101-61.

10. Leigh RJ, Kennard C. Using saccades as a research tool in the clinical neurosciences. Brain. 2004;127(Pt 3):460-77.

11. Reddi BA, Carpenter RH. The influence of urgency on decision time. Nat Neurosci. 2000;3(8):827-30.

12. Carpenter RH. The saccadic system: a neurological microcosm. ACNR. 2004;4(1):6-8.
13. Brigell MG, Goodwin JA, Lorance R. Saccadic latency as a measure of afferent visual conduction. Invest Ophthalmol Vis Sci. 1988;29(8):1331-8.

14. Reulen JP. Latency of visually evoked saccadic eye movements. II. Temporal properties of the facilitation mechanism. Biol Cybern.1984;50(4):263-71.

15. Kanjee R, Yücel YH, Steinbach MJ, González EG, Gupta N. Delayed saccadic eye movements in glaucoma. Eye Brain. 2012; 4:63-8.

16. Pearson BC, Armitage KR, Horner CW, Carpenter RH. Saccadometry: the possible application of latency distribution measurement for monitoring concussion. Br J Sports Med. 2007; 41(9):610-2.

17. Williams IM, Ponsford JL, Gibson KL, Mulhall LE, Curran CA, Abel LA. Cerebral control of saccades and neuropsychological test results after head injury. J Clin Neurosci. 1997;4(2):186-96.

18. Heitger MH, Anderson TJ, Jones RD. Saccade sequences as markers for cerebral dysfunction following mild closed head injury. Prog Brain Res. 2002;140:433-48.

19. Heitger MH, Jones RD, Dalrymple-Alford JC, Frampton CM, Ardagh MW, Anderson TJ. Motor deficits and recovery during the first year following mild closed head injury. Brain Inj 2006; 20(8):807-24.

20. Carroll LJ, Cassidy JD, Holm L, Karus J, Coronado VG; WHO Collaborating Centre Task Force on Mild Traumatic Brain Injury. Methodological issues and research recommendations for mild traumatic brain injury: the WHO Collaborating Center Task Force on Mild Traumatic Brain Injury. J Rehabil Med. 2004;(43 Suppl):113-25.

21. Reilly JL, Lencer R, Bishop JR, Keedy S, Sweeney JA. Pharmacological treatment effects on eye movement control. Brain Cogn. 2008;68(3):415-35.

22. Sweeney JA, Brew BJ, Kelip JG, Sidtis JJ, Price RW. Pursuit movement dysfunction in HIV-1 seropositive individuals. J Psychiatry Neurosci. 1991;16(5):247-52.

23. Alessandrini M, Bruno E, Parisi V, Uccioli L, Giacomini PG. Saccadic eye movement and visual pathways function in diabetic patients. An Otorrinolaringol Ibero Am. 2001;28(3):269-80.

24. Munoz DP, Broughton JR, Goldring JE, Armstrong IT. Age-related performance of human subjects on saccadic eye movement tasks. Exp Brain Res. 1998;121(4):391-400.

25. Irving EL, Steinbach MJ, Lillakas L, Babu RJ, Hutchings N. Horizontal saccade dynamics across the human life span. Invest Ophthalmol Vis Sci. 2006;47(6):2478-84.

26. Radloff LS. The CES-D Scale: A self-report depression scale for research in the general population. Appl Psychol Meas. 1977; 1(3):385-401.

27. Winograd-Gurvich C, Georgiou-Karistianis N, Fitzgerald PB, Millist L, Whilte OB. Self-paced and reprogrammed saccades: differences between melancholic and non-melancholic depression. Neurosci Res. 2006;56(3):253-60.

28. McCauley SR, Pedroza C, Brown SA, et al. Confirmatory factor structure of the Center for Epidemiological Studies Depression Scale (CES-D) in mild-to-moderate traumatic brain injury. Brain Inj. 2006;20(5):519-27.

29. Bay E, Hagerty BM, Williams RA. Depressive symptomatology after mild-to-moderate traumatic brain injury: a comparison of three measures. Arch Psychiatr Nurs. 2007;21(1):2-11.

30. Macciocchi SN, Barth JT, Alves W, Rimel RW, Jane JA. Neuropsychological functioning and recovery after mild head injury in collegiate athletes. Neurosurgery. 1996;39(3):510-4.

31. McCrea M, Guskiewicz KM, Marshall SW, et al. Acute effects and recovery time following concussion in collegiate football players: the NCAA Concussion Study. JAMA. 2003;290(19): 2556-63.

32. Pellman EJ, Lovell MR, Viano DC, Casson IR. Concussion in professional football: recovery of NFL and high school athletes assessed by computerized neuropsychological testing - Part 12 . Neurosurgery. 2006;58(2):263-74.

33. Lannsjö M, Borg J, Björklund G, Af Geijerstam JL, LündgrenNilsson A. Internal construct validity of the Rivermead PostConcussion Symptoms Questionnaire. J Rehabil Med. 2011;43 (11):997-1002. 
34. King NS, Crawford S, Wenden FJ, Moss NE, Wade DT. The Rivermead Post-Concussion Symptoms Questionnaire: a measure of symptoms commonly experienced after head injury and its reliability. J Neurol. 1995;242(9):587-92.

35. Falconer EK, Geffen GM, Olsen SL, McFarland K. The rapid screen of concussion: an evaluation of the non-word repetition test for use in mTBI research. Brain Inj. 2006;20(12):1251-63.

36. Bazarian JJ, Atabaki S. Predicting postconcussion syndrome after minor traumatic brain injury. Acad Emerg Med. 2001;8(8): 788-95.

37. Echemendia RL, Putukian M, Mackin RS, Julian LJ, Shoss N. Neuropsychological test performance prior to and following sports-related mild traumatic brain injury. Clin J Sports Med. 2001;11(1):23-31.

38. Lange RT, Iverson GL, Franzen MD. Neuropsychological functioning following complicated vs. uncomplicated mild traumatic brain injury. Brain Inj. 2009;23(2):83-91

39. Preece MH, Geffen GM. The contribution of pre-existing depression to the acute cognitive sequelae of mild traumatic brain injury. Brain Inj. 2007;21(9):951-61.

40. Lovell MR, Solomon GS. Psychometric data for the NFL neuropsychological test battery. Appl Neuropsychol. 2011;18(3): 197-209.

41. Echemendia RJ, Herring S, Bailes J. Who should conduct and interpret the neuropsychological assessment in sports-related concussion? Br J Sports Med. 2009;43(Suppl 1):i32-5.

42. Sherman EMS, Spreen O. A Compendium of Neuropsychological Tests: Administration, Norms and Commentary. 3rd ed. Strauss E, editor. New York: Oxford University Press; 2006. p. 767.

43. Ober JK, Przedpelska-Ober E, Gryncewicz W, et al. Handheld system for ambulatory measurement of saccadic durations of neurological patients. In: Gajda J, editor. Modelling and measurement in medicine. Warsaw: Komitet Biocybernityki I Inzyneierii Biomedycznej PAN; 2003. p. 187-98.

44. Pierrot-Deseilligny C, Rivaud S, Gaymard B, Agid Y. Cortical control of reflexive visually-guided saccades. Brain. 1991;114 (Pt 3):1473-85.

45. Michell AW, Xu Z, Fritz D, et al. Saccadic latency distributions in Parkinson's disease and the effects of L-dopa. Exp Brain Res. 2006;174(1):7-18

46. Rivaud S, Muri RM, Gaymard B, Vermersch AI, PierrotDeseilligny C. Eye movement disorders after frontal eye field lesions in humans. Exp Brain Res. 1994;102(1):110-20.

47. Fischer B, Weber H, Biscaldi M, Aiple F, Otto P, Sturh V. Separate populations of visually guided saccades in humans: reaction times and amplitudes. Exp Brain Res. 1993;92(3):528-41.
48. Shafiq-Antonacci R, Maruff P, Whyte S, Tyler P, Dudgeon P, Currie $\mathrm{J}$. The effects of age and mood on saccadic function in older individuals. J Gerontol B Psychol Sci Soc Sci. 1999;54(6): P361-8.

49. Sparks D, Rohrer WH, Zhang Y. The role of the superior colliculus in saccade initiation: a study of express saccades and the gap effect. Vision Res. 2000;40(20):2763-77.

50. Fischer B, Biscaldi, M, Gezeck S. On the development of voluntary and reflexive components in human saccade generation. Brain Res. 1997;754(1-2):285-97.

51. Schmidt JD, Register-Mihalik JK, Mihalik JP, Kerr ZY, Guskiewicz KM. Identifying impairments after concussion: normative data versus individualized baselines. Med Sci Sports Exerc. 2012;44 (9): $1621-8$

52. Antoniades CA, Altham PM, Mason SL, Barker RA, Carpenter R. Saccadometry: a new tool for evaluating presymptomatic Huntington patients. Neuroreport. 2007;18(11):1133-6.

53. Burrell JR, Hornberger M, Carpenter RH, Kiernan MC, Hodges, JR. Saccadic abnormalities in frontotemporal dementia. Neurology. 2012;78(23):1816-23.

54. Heitger MH, Jones RD, Macleod AD, Snell DL, Frampton CM, Anderson TJ. Impaired eye movements in post-concussion syndrome indicate suboptimal brain function beyond the influence of depression, malingering or intellectual ability. Brain. 2009;132(Pt 10):2850-70.

55. Kelly JP, Rosenberg JH. Diagnosis and management of concussion in sports. Neurology. 1997;48(3):575-80.

56. Heitger MH, Macaskill MR, Jones RD, Anderson TJ. The impact of mild closed head injury on involuntary saccadic adaptation: evidence for the preservation of implicit motor learning. Brain Inj. 2005;19(2):109-17.

57. Ponsford J, Willmott C, Rothwell A, et al. Factors influencing outcome following mild traumatic brain injury in adults. J Int Neuropsychol Soc. 2000;6(5):568-79.

58. Bazarian JJ, Wong T, Harris M, Leahey N, Mookerjee S, Dombovy M. Epidemiology and predictors of post-concussive syndrome after minor head injury in an emergency population. Brain Inj. 1999;13(3):173-89.

59. Laker SR. Epidemiology of concussion and mild traumatic brain injury. PM R. 2011;(10 Suppl 2):S354-8.

60. Harmon KG, Drezner JA, Gammons M, et al. American Medical Society for Sports Medicine position statement: concussion in sport. Br J Sports Med. 2013;47(1):15-26. 